\title{
EVALUATION OF EROSION RATES IN CADASTRAL AREA ROVEČNÉ (MORAVIA) USING GIS TOOLS
}

\author{
Tomáš Mašíček, Jana Kozlovsky Dufková, Tomáš Zámečník ${ }^{1}$
}

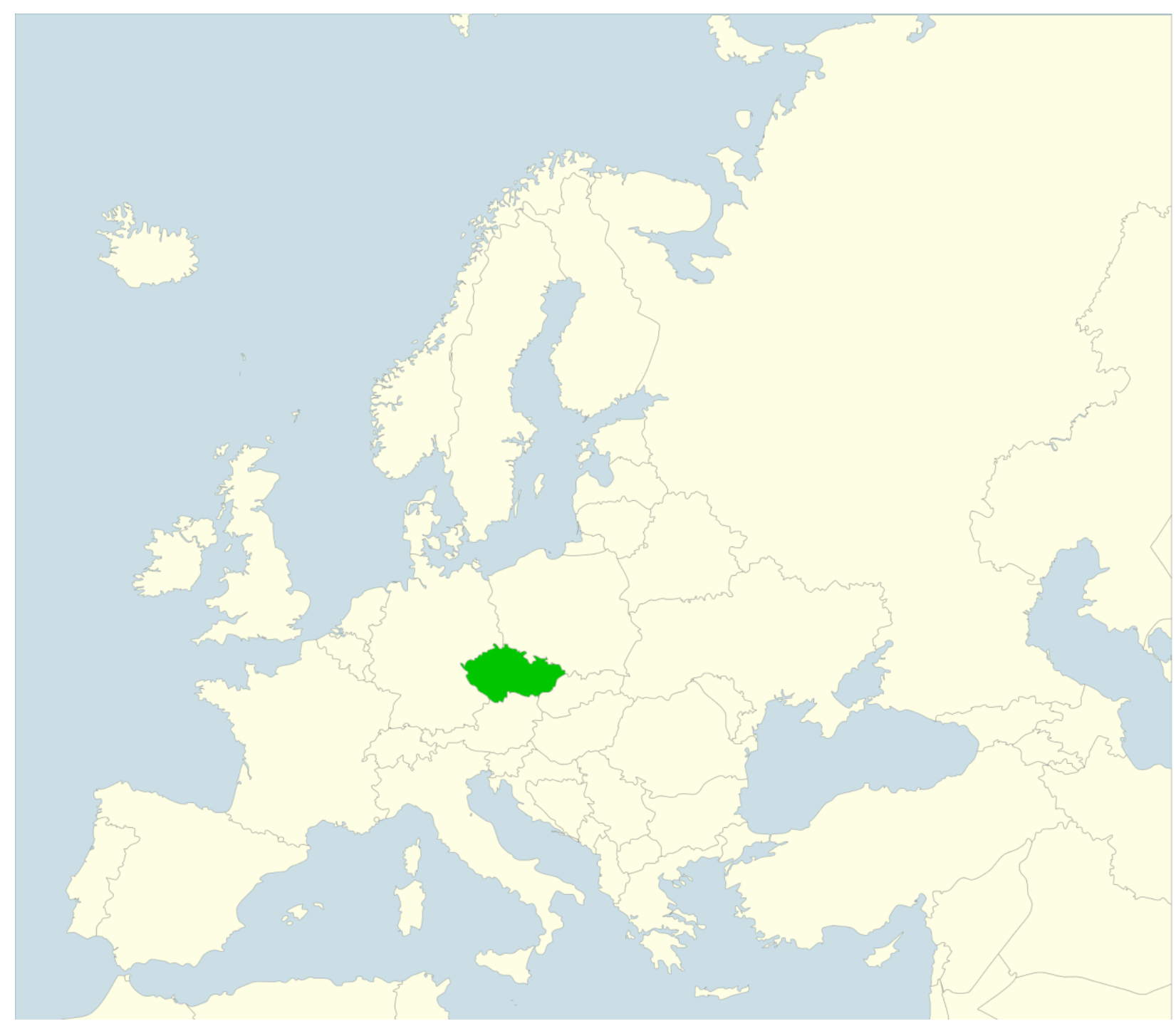

\footnotetext{
1 Ing. Tomáš Mašíček, Ph.D., tomas.masicek@mendelu.cz; Doc. Ing. Jana Kozlovsky Dufková, Ph.D., jana.dufkova@mendelu.cz; Ing. Tomáš Zámečník, zamecnik.t@seznam.cz; Department of Applied and Landscape Ecology, Faculty of Agronomy, Mendel University in Brno, Zemědělská 1, 61300 Brno, the Czech Republic
} 
Abstract: Evaluation of the vulnerability of agricultural land by water erosion, including the erosion control measures design, was done using the geographic information systems (GIS) on example of the cadastral area Rovečné, the Czech Republic. Analytical operations that lead to evaluation of the basic runoff and especially erosion rates according to the Universal Soil Loss Equation (USLE) were made in ArcGIS 10 Desktop, the software product Arclnfo using a set of integrated software applications ArcMap, ArcCatalog and user interface ArcToolbox, and also using programs LS-converter and USLE2D. The potential loss of soil by water erosion was determined before and after erosion control measures design. The proposed measures should improve the current situation and contribute to preservation of agricultural activity in this area in a form close to the current situation.

Key words: cadastral area Rovečné, water erosion, USLE, ArcGIS, LS-converter, USLE2D

Souhrn: Vyhodnocení ohroženosti zemědělské půdy vodní erozí včetně návrhu protierozních opatření za využití geografických informačních systémů (GIS) je demonstrováno na příkladu katastrálního území Rovečné nacházejícího se v České republice. Analytické operace vedoucí $\mathrm{k}$ vyhodnocení základních odtokových a především erozních poměrů dle univerzální rovnice ztráty půdy (USLE) byly provedeny v programu ArcGIS 10 Desktop, v softwarovém produktu Arclnfo pomocí sady integrovaných softwarových aplikací ArcMap, ArcCatalog a uživatelského rozhraní ArcToolbox a dále v programech LS-converter a USLE2D. Potenciální ztráta pưdy vodní erozí byla stanovena před a po návrhu protierozních opatření. Navrženými opatřeními by mělo dojít ke zlepšení stávajícího stavu a zároveň k udržení zemědělské činnosti na tomto území v podobě blízké současnému stavu.

Klíčová slova: katastrální území Rovečné, vodní eroze, USLE, ArcGIS, LS-converter, USLE2D

\section{Introduction}

Soil erosion is a natural process that causes loss of topsoil. Erosion can be induced by natural elements such as water, wind, snow, ice, plants or animals, or can be induced by human activities (above all by agriculture).

The process of erosion generally consists of three distinct actions - soil detachment, movement and deposition. Topsoil, which is high in organic matter, fertility and soil life, is moved to another place, which means decrease in agricultural productivity "on-site". The topsoil can be also carried "off-site", where causes sedimentation of waterways and eutrophication of water.

Erosion means not only the loss of soil particles but also loss of natural nutrients and possible fertilizers. Seeds can be disturbed or removed and pesticides can be carried off. Loss of soil structure and stability, and negative affecting of soil texture are other problems that can be caused by erosion.

Erosion is a major source of soil degradation, in EU causes annual losses estimated at 14 billion euros (www.soilconservation.eu). 50 percent of agricultural soils are threatened by water erosion in the Czech Republic; 450,000 hectares (thus more than ten percent) of the agricultural land is damaged seriously. Water erosion washes away about 21 million tonnes of topsoil every year. Another 14 percent of agricultural land is vegetative cover and tillage practices:

\section{- Precipitation}

The amount and intensity of precipitation is the main factor influencing water erosion. From erosion point of view, the most dangerous situation arises when heavy rain occurs at times or in locations where the soil surface is not well protected by vegetation. 
The size and velocity of raindrops is also an important factor. Raindrops falling on the soil surface can break down soil aggregates and disperse the aggregate material. Larger raindrops with higher velocity have greater kinetic energy, therefore their influence on soil disturbance will be greater than for smaller raindrops (Auzet et al., 2004).

\section{- Soil erodibility}

The soil erodibility expresses the susceptibility of soil to erosion, in other words ability of soil to resist erosion. Soil erodibility depends on the physical characteristics of soil, i.e. on soil structure and texture, content of organic matter and permeability. Generally, the sandy soils are less erodible than clay-textured soils (Barthès and Roose, 2002).

\section{- Topography}

The topography of the land influences the rate of surface runoff. Steeper, longer slope is much more susceptible to erosion during heavy rains than less steep, shorter slope (Feng et al., 2010).

Consolidation of small fields into larger ones, which was characteristic for the period of 1970s 1980s in terms of socialization of Czech countryside (and unfortunately, large areas of fields remain to this day), results in longer slope lengths with increased erosion potential.

\section{- Vegetative cover}

The vegetative cover protects the soil directly, so that it protects the soil surface from the destructive effects of falling raindrops, slows down the surface runoff rate, and help to infiltrate the water from rain. The indirect effect of the vegetative cover consists in the increasing of porosity and permeability of the soil. The roots of the plants bind up the soil together and form a more stable mass that is less susceptible to erosion (Zheng, 2006).

Forests and grasses are the best protection against erosion, because they protect the soil enough and help to intercept raindrops. On the other hand, crops like maize, potatoes or beet (row-crop) have the worst effect of erosion control, because they are grown in the wide row thus mostly unprotected bare soil.

\section{- $\quad$ Tillage practices}

The tillage practices are the other important factor in erosion control. The depth of tillage, its direction, type of equipment and timing during the vegetation period influence the potential erosion. Tillage causes disruption of soil aggregates and their washing away by surface runoff in case of heavy rain (Morgan, 2009). On the other hand, no-till practices are not already recommended nowadays because of poor infiltration of water due to poorly loosened soil.

Simple methods such as the Universal Soil Loss Equation (USLE) (Wischmeier and Smith, 1978), the Modified Universal Soil Loss Equation (MUSLE) (Williams, 1975), or the Revised Universal Soil Loss Equation (RUSLE) (Renard et al., 1991) are frequently used for evaluation of erosion rates from catchment areas (e.g. Ferro and Minacapilli, 1995; Efe et al., 2000; Zheng et al., 2014). The use of Geographical Information Systems (GIS) methodology is well suited for the quantification of heterogeneity in the topographic and drainage features of a catchment (e.g. Rodda et al., 1999; Bartsch et al., 2002).

GIS tools allow you to quickly and efficiently evaluate the actual vulnerability of agricultural soils to water erosion as well as the effectiveness of erosion control measures proposed through the USLE. The indisputable advantage of the use of GIS is also visualization of the analysis results leading to the calculation of the USLE factors and ultimately soil erosion risks for specific parts of land parcels in the area of interest.

The objective of this research was to use GIS for the evaluation of vulnerability of agricultural soil by water erosion before and after design of erosion control measures in the cadastral area Rovečné. 


\section{Materials and Methods}

\subsection{Study area}

The study cadastral area Rovečné $(49.58 \mathrm{~N}, 16.36 \mathrm{E})$ is situated eastwards of the capital city of Prague in the region of Vysočina, district of Žd'ár nad Sázavou (the Czech Republic) (Fig. 1-2), and covers an area of $9.83 \mathrm{~km}^{2}$. Altitude of the area is $572-774 \mathrm{~m}$ above the sea level.

The cadastral area, instead of catchment or sub-catchment, was select as a study area, because the land consolidation, which solve soil erosion control, are performed within the cadastral area as the basic unit.

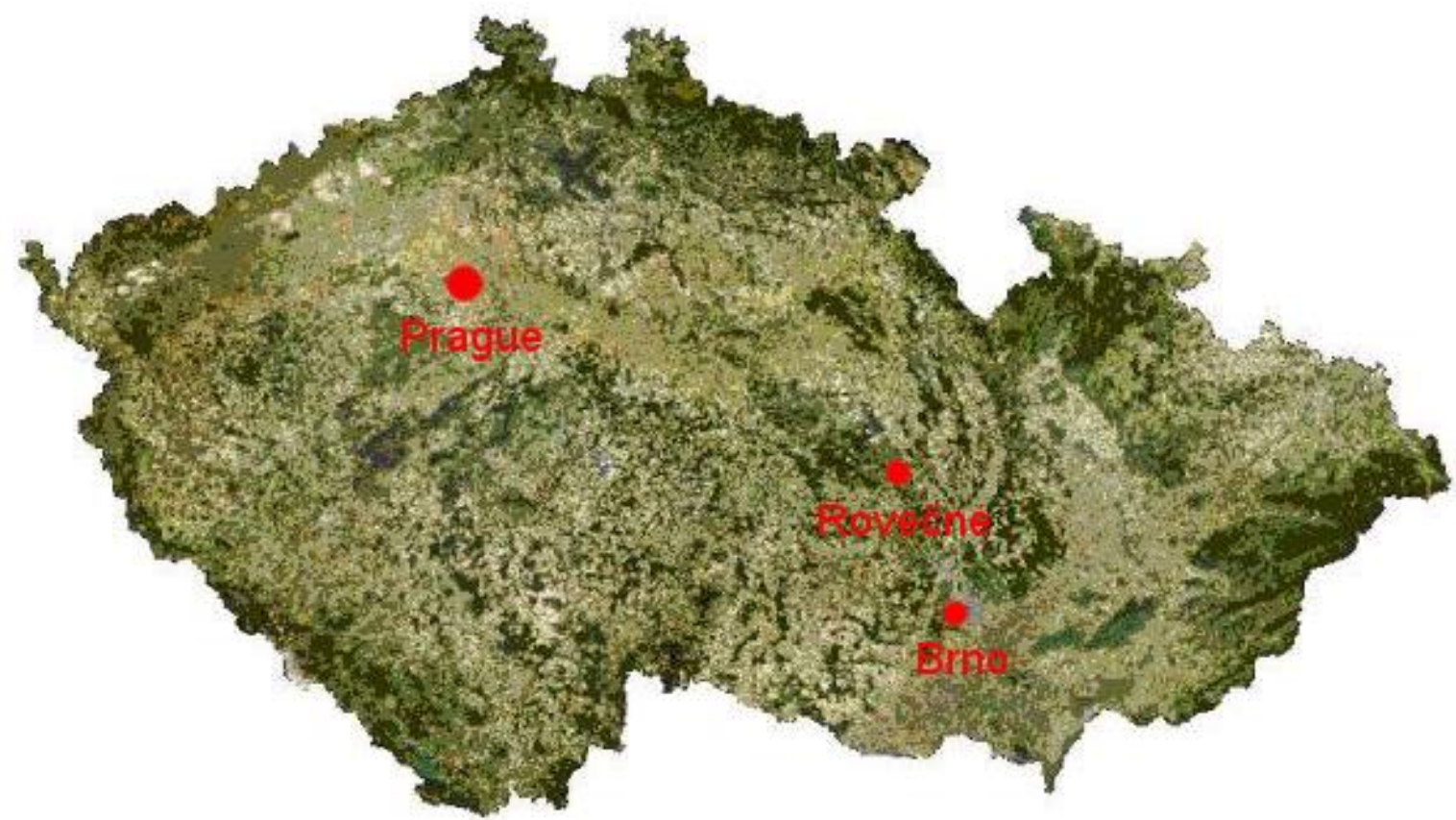

Fig 1. Location of cadastral area Rovečné, the Czech Republic. Data source: orthophotomap - @ ČÚZK, www.cuzk.cz

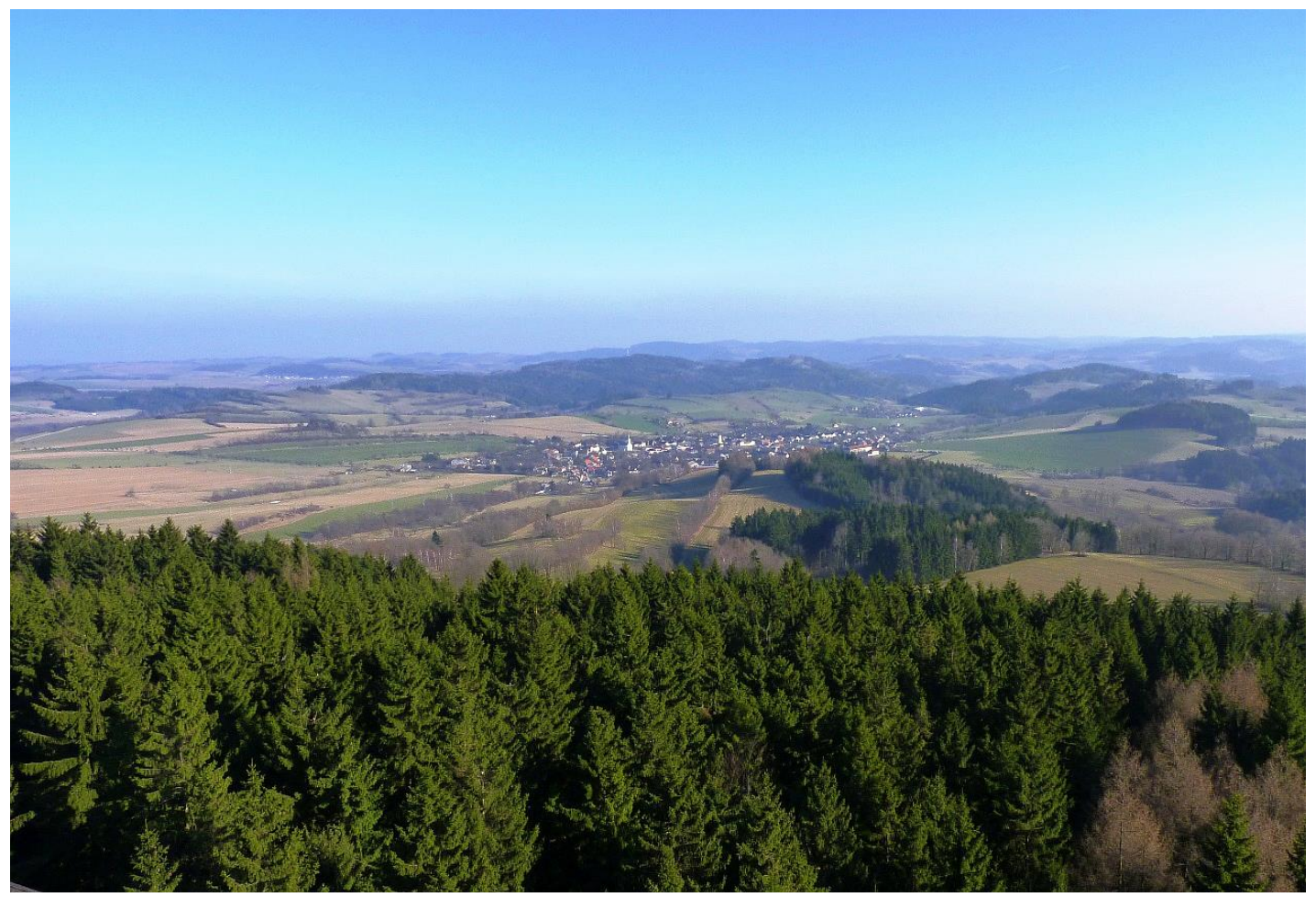

Fig 2. Cadastral area Rovečné from viewing tower Horní les. 
Climate region of the area is MW4 - region with a slightly cool, wet climate with an average annual temperature of $5-7^{\circ} \mathrm{C}$. The average annual rainfall for the region is 650 to $800 \mathrm{~mm}$ (Tolasz et al., 2007).

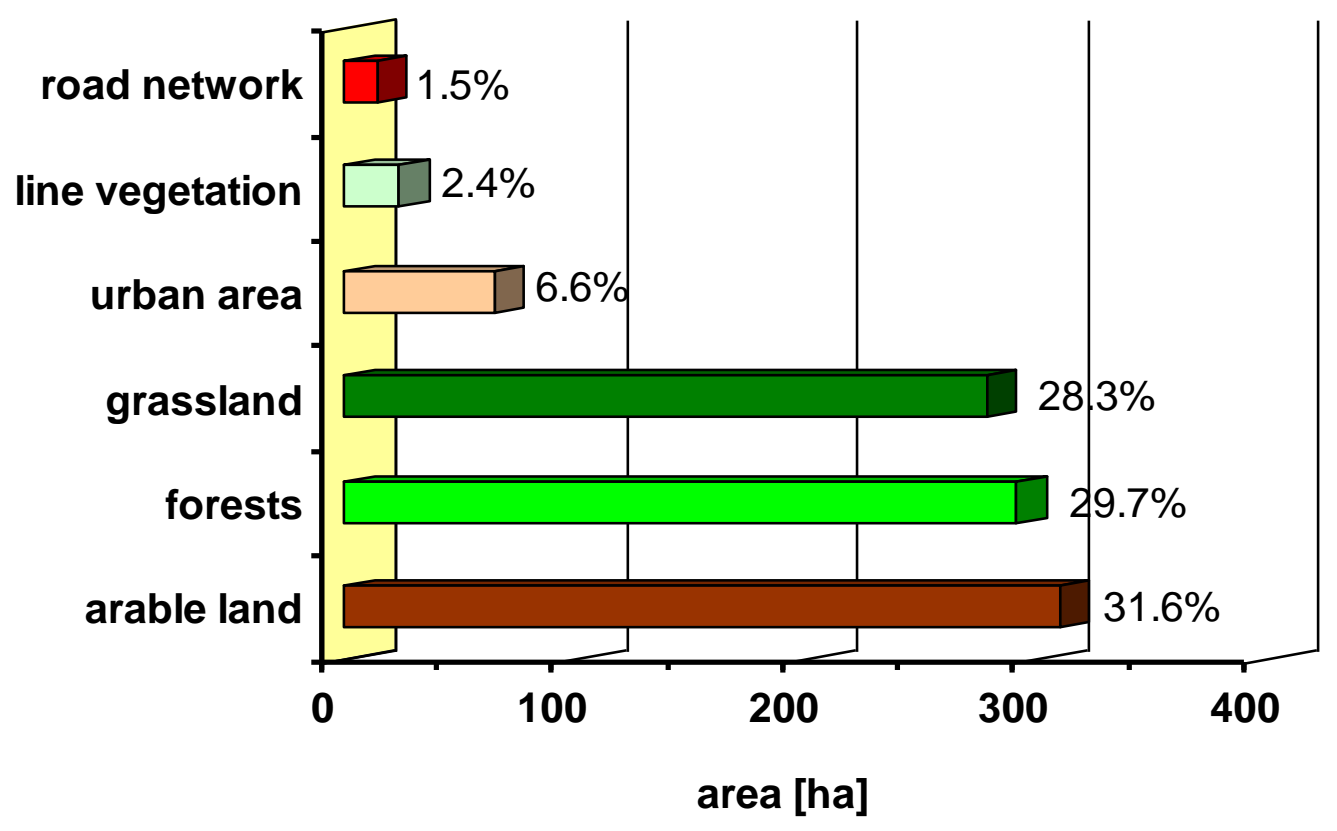

Fig 3. Type of land in the cadastral area Rovečné and its percentages. Data source: orthophotomap(c) ČÚZK, www.cuzk.cz

Gneiss and granulit are prevailing soil-forming substrate of the soils in the cadastral area Rovečné according to the synthetic soil map of the Czech Republic (Novák et al., 1993). The predominant soil type is cambisols dystric, insularly occurring cambisols modal and lesser extent gleys. The main soil units (HPJ) occurring in the area of interest are: HPJ 29, 34, 37, 40, 50, 64 and 68. Their characteristics are listed in the official announcement of Ministry of Agriculture no. 327/1998. These are soils with a depth from medium deep to deep.

Land use is mainly agricultural. Most of the agricultural land is farmed by one collective farm. The farm is engaged in crop and livestock production, therefore the species composition of crops is quite varied. Part of grassland is used as grazing land for cattle and sheep. A detailed description of the land use is shown in the Fig. 3 and 4. 


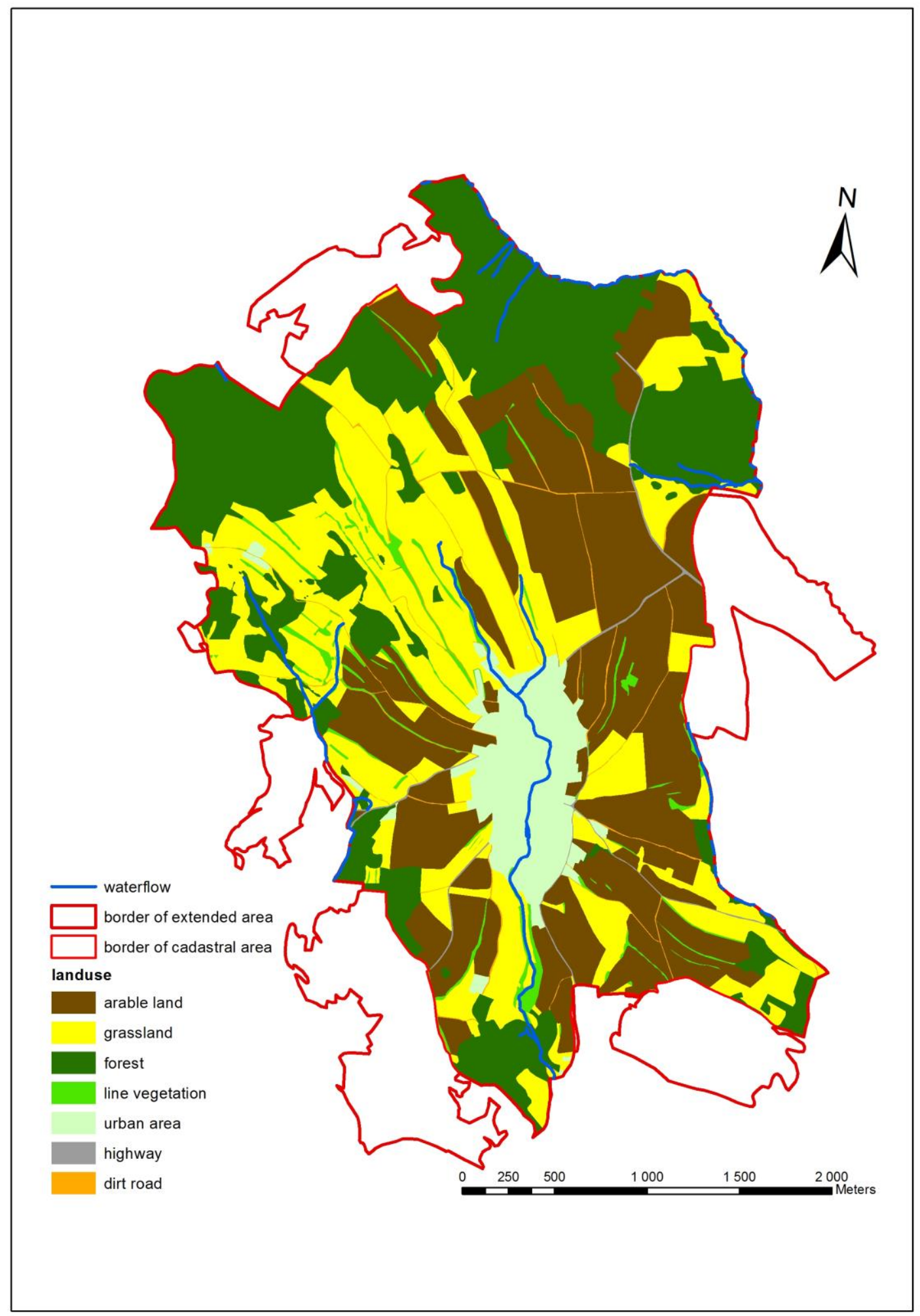

Fig 4. Land use of the cadastral area Rovečné (layer Land_Use).

\subsection{Methods and Input Data}

Methods such as the USLE have been found to produce realistic estimates of surface erosion over areas (Wischmeier and Smith, 1978). Therefore, soil erosion within a grid cell was estimated via the USLE. The USLE is expressed as (1):

$$
A=R \times K \times L S \times C \times P
$$


where $A$ is the average annual soil loss [t.ha ${ }^{-1}$ per year], $R$ is the rainfall-runoff factor [MJ.ha- ${ }^{-1} \cdot \mathrm{cm} \cdot \mathrm{h}^{-1}$ ], $\mathrm{K}$ is the soil erodibility factor [t.ha.h.ha- ${ }^{-1} \cdot \mathrm{MJ}^{-1} \cdot \mathrm{cm}^{-1}$ ], LS is the topographic factor (dimensionless), $\mathrm{C}$ is the cover-management factor (dimensionless), and $\mathrm{P}$ is the supporting practice factor (dimensionless). ${ }^{2}$

Preparation, processing of background data and analysis leading to evaluation of erosion risks were made in ArcGIS Desktop 10, software product Arclnfo using a set of integrated software applications ArcMap, ArcCatalog and ArcToolbox user interface, as well as in programs USLE2D and LS-converter.

The digital map of the cadastral area was prepared and converted as a vector layer from a file geodatabase called AdministrativniCleneni_v12.gdb of digital vector geographic database of the Czech Republic ArcČR 500 (Map data (C) ARCDATA PRAGUE Ltd., Czech Geodetic and Cadastral Office and Czech Statistical Office, www.arcdata.cz). The basis for hydrographic network was obtained using digital data from A02_Vodni_tok_JU from water management data base (DIBAVOD) (Map data (C) VÚV TGM, www.dibavod.cz).

A layer Land_Use of the study area was prepared and converted into digital form from raster base map (ZM10), colour digital orthophotomap (Map data (C) ČÚZK, www.cuzk.cz) and map of Land Parcel Identification System (LPIS) (Map data (C) Ministry of Agriculture, www.eagri.cz) using Web Map Service (WMS). The layer displays current state of land cover. Similarly, a digital layer of Soil_Blocks was created showing only the blocks of arable land and permanent grassland limitary by roads with ditches, green belts, forests, watercourses or other interruptions of slope length along the fall line. On the basis of the layer, the determined and calculated factors of the USLE were then displayed and then the average annual soil loss by water erosion was calculated, including representation of erosion degrees of individual plots.

Determination of the individual factors of the USLE is based on actual knowledge taking into account the conditions of the Czech Republic as reflected in the methodology Janeček et al. (2012).

The rainfall factor $\mathrm{R}$ can vary from year to year, so an average over a number of years is usually used. Of the USLE factors, is the one most exactly computed from input data i.e., rainfall amounts and intensities. However, these data are not always readily available in several areas of the world. Therefore, the rainfall factor, $\mathrm{R}$, is the first factor modified. Published $\mathrm{R}$ values represent erosivity during an average year. Rainfall is highly variable from year to year and month to month in a year as some month in a year wettest and some are dry. For these reasons, the $\mathrm{R}$ factor needs to be adapted to a climatic region. The simplest method is to use the yearly average of rainfall over number of years as rainfall factor (Hernando and Romana, 2015).

In the USLE, the soil erodibility factor $\mathrm{K}$ corresponds to the collective effects of the detachment susceptibility of soil and the sediment transportability as well as the amount and rate of runoff under a given rainfall erosivity (Shabani et al., 2014). The factor $\mathrm{K}$ in this work was determined on the basis of the soil ecological units (BPEJ) of the digital layer called BPEJ (Janeček et al., 2012). BPEJ is a unique system that specifies in detail and very precisely the main soil and climatic conditions of the studied area and is listed in numerical and cartographic form in the national database of BPEJ which is ready for territory of the Czech Republic (official announcement of Ministry of Agriculture no. 327/1998). Tool Extract-Clip performed cropping of the layer showing the value of factor $\mathrm{K}$ in the whole area by layer of Soil_Blocks. The output of this was the vector layer $K$ _factor. Then the layer $K \_$factor had to be converted to raster format for calculation of erosion loss.

The topographic factor LS consists of two sub-factors - a slope gradient factor $S$ and a slope length factor L. Program USLE2D was used for calculation of topographic factor (van Oost and Govers, 2000). USLE2D is designed to calculate the topographic factor from a grid-based Digital Elevation Model (DEM). DEM is a quantitative representation of the Earth's surface that provides basic information about the terrain and allows for the derivation of attributes such as slope, aspect, drainage area and network, curvature, and topographic index (Mukherjee et al., 2014). In a real

\footnotetext{
2 these units are used according to Renard et al. (1991)
} 
two-dimensional situation overland flow and the resulting soil loss do not really depend on the distance to the divide or upslope border of the field, but on the area per unit of contour length contributing runoff to that point. The latter may differ considerably from the manually measured slope length, as it is strongly affected by flow convergence and/or divergence. USLE2D overcomes this problem by replacing the slope length by the unit contributing area. USLE2D provides different routing algorithms for calculating the contributing area and various LSalgorithms (Fistikoglu and Harmancioglu, 2002).

The linkage of USLE2D in a GIS offers several advantages to the one-dimensional and/or manual approach; it may account for the effect of flow convergence on rill development and it has advantages in terms of speed of execution and objectivity. The linking of USLE2D with a GIS facilitates the application of the (R)USLE to complex land units, thereby extending the applicability and flexibility of the (R)USLE in land resources management (Panagos et al., 2015).

Program USLE2D requires as input data DEM, as already stated, and layer Soil_Blocks. Layer Soil_Blocks divides the territory to sub-areas. The calculation is based on the assumption that the boundaries between blocks work as barriers to surface runoff, an interruption of runoff occurs here. The length of the runoff lines and factor $L$ are then reduced. The program USLE2D calculates factor LS separately for each raster element. The length of the runoff line is replaced by a contributing area.

Raster layer of DEM was generated by the tool Interpolation - Topo to Raster on the base of vector layer ZABAGED Altimetry - 3D Contour Lines and vector file with the boundaries of the area. DEM had to be evened out to remove the imperfections of the resulting surface such as dips and peaks. Even grid (DMT_Fill) was created using tool Hydrology - Fill.

To get an overview of basic hydrological characteristics, respectively of runoff (layer LS_factor), layers Flow_Direction, Flow_Accumulation and Flow_Length were created. The layer Flow_Direction was created using tool Hydrology - Flow Direction and DMT_Fill as a source file. Layers Flow_Accumulation and Flow_Length were then created on the basis of layer Flow_Direction using tools Hydrology - Flow Accumulation and Hydrology - Flow Length.

The factor $C$ describes the relation between the erosion on bare soil and the erosion on cropped conditions. Factor $\mathrm{C}$ was determined on the basis of crop rotations (only on the arable land) for the period of 2009-2013. Five representative crop rotations that were used by collective farm on individual soil blocks were included into the calculation of erosion loss (Tab. 1). Calculations of factors $\mathrm{C}$ on the individual blocks were carried out according to the Wischmeier and Smith (1978) in Janeček et al. (2012). The method of calculation of the factor $C$ is an accurate way to quantify the value of factor $\mathrm{C}$, which reflects crop rotation, used agricultural technologies and individual growing periods of each crop, including the period between crop rotation. Vector layer $C_{-}$factor showing the value of factor $\mathrm{C}$ of each block was then converted to raster format.

Tab 1. Crop rotations included into the calculation of the factor $C$.

\begin{tabular}{|c|c|c|c|c|c|}
\hline Year/crop rotation & 1 & 2 & 3 & 4 & 5 \\
\hline 2009 & alfalfa & maize & oat & alfalfa & winter rape \\
\hline 2010 & alfalfa & spring barley & winter wheat & winter rape & winter wheat \\
\hline 2011 & winter rape & winter rape & maize & winter wheat & oat \\
\hline 2012 & winter wheat & maize & spring barley & oat & winter rape \\
\hline 2013 & winter rape & spring barley & winter rape & winter wheat & winter wheat \\
\hline
\end{tabular}

The factor $P$ represents erosion reducing measures like terraces or ridging/contouring. The $\mathrm{P}$-factor is assigned the value of 1 when no influences from conservation practices are considered. If conservation measures are taken the value will decrease and thereby lower the estimated erosion (Kuok et al., 2013).

In order to apply the USLE in a GIS, every parameter is organized as a thematic layer which is providing a spatial distribution. The layers need to be of the type raster, which means that they are in the form of grid nets (matrixes). In the spatial distribution of the raster, every grid cell has 
a unique parameter value and the model is executed by an overlay operation that multiplies all the parameter layers mathematically. This means that every single cell is overlaid (multiplied) with its spatially corresponding cells in the other parameter layers, completing the multiplication of the equation. The output of the model is a combined layer where every single cell value is the product of the equation. Finally, the whole layer is summed and the average annual soil loss per hectare is calculated (Bartsch et al., 2002).

The calculation of average annual soil loss was done using a tool Map Algebra - Raster Calculator. Individual factors of the USLE, either in the numerical form (factor $R$ and $P$ ) or as raster layers ( $K$ _factor, $L S \_$factor, $C \_$factor) entered into the equation. A raster layer $A \_$erosion was the result, where soil loss values in t.ha $^{-1}$ per year were distributed into seven classes (erosion rates).

Another representation of annual soil loss was created using a tool Zonal-Zonal Statistics, when vulnerability of soil by water erosion was expressed by four vulnerability degrees according to the multiple of soil loss tolerance $T$ (erosion light $\leq 1 \times T$, medium $\leq 2 \times T$, strong $\leq 3 \times T$ and very strong $>3 \times \mathrm{T}$ ). Soil loss tolerance is the amount of soil that could be lost without a decline in fertility, thereby maintaining crop productivity indefinitely (Lal, 2006). Soil loss tolerance is determined on the basis of soil depth (Janeček et al., 2012). Soils in the area of interest are moderately deep $\left(30-60 \mathrm{~cm}\right.$ ) and deep (over $60 \mathrm{~cm}$ ), the soil loss tolerance is therefore 4 t.ha $^{-1}$ per year.

Design of erosion control measures, which included organizational and agronomic measures in two phases, was performed. Subsequently, the recalculation of annual soil loss was done and erosion vulnerability degrees on individual blocks were determined.

More detailed description of operations and analysis in ArcGIS is described in the publications of Dumbrovský et al. (2008), Mašíček (2010), Longley et al. (2011), Geletič et al. (2013), Schmidts (2013), Mašíček and Ždímal (2014).

\section{Results and Discussion}

\subsection{Calculation of Average Annual Soil Loss}

The USLE was applied to predict soil loss magnitude and GIS software ArcView and ArcMap was used to simulate the soil loss in spatial distribution. Each one of the USLE-parameters (rainfall erosivity $R$, soil erodibility $K$, topography LS, land use $C$ and conservation practice $P$ ) were represented by a thematic raster layer in the GIS.

Value of the factor $R$ was determined according to the methodology of Janeček et al. (2012) which is based on the method of Wischmeier and Smith (1958). The value of the factor $R$ is

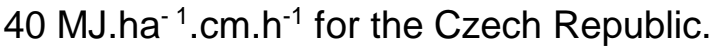

Soil erodibility expressed through factor $\mathrm{K}$ is shown in the Fig. 5 . Values of the factor $\mathrm{K}$ range from 0.16 to 0.49 t.ha.h.ha-1 $\cdot \mathrm{MJ}^{-1} \cdot \mathrm{cm}^{-1}$. The higher the value of factor $\mathrm{K}$, the greater vulnerability of soil to water erosion. 


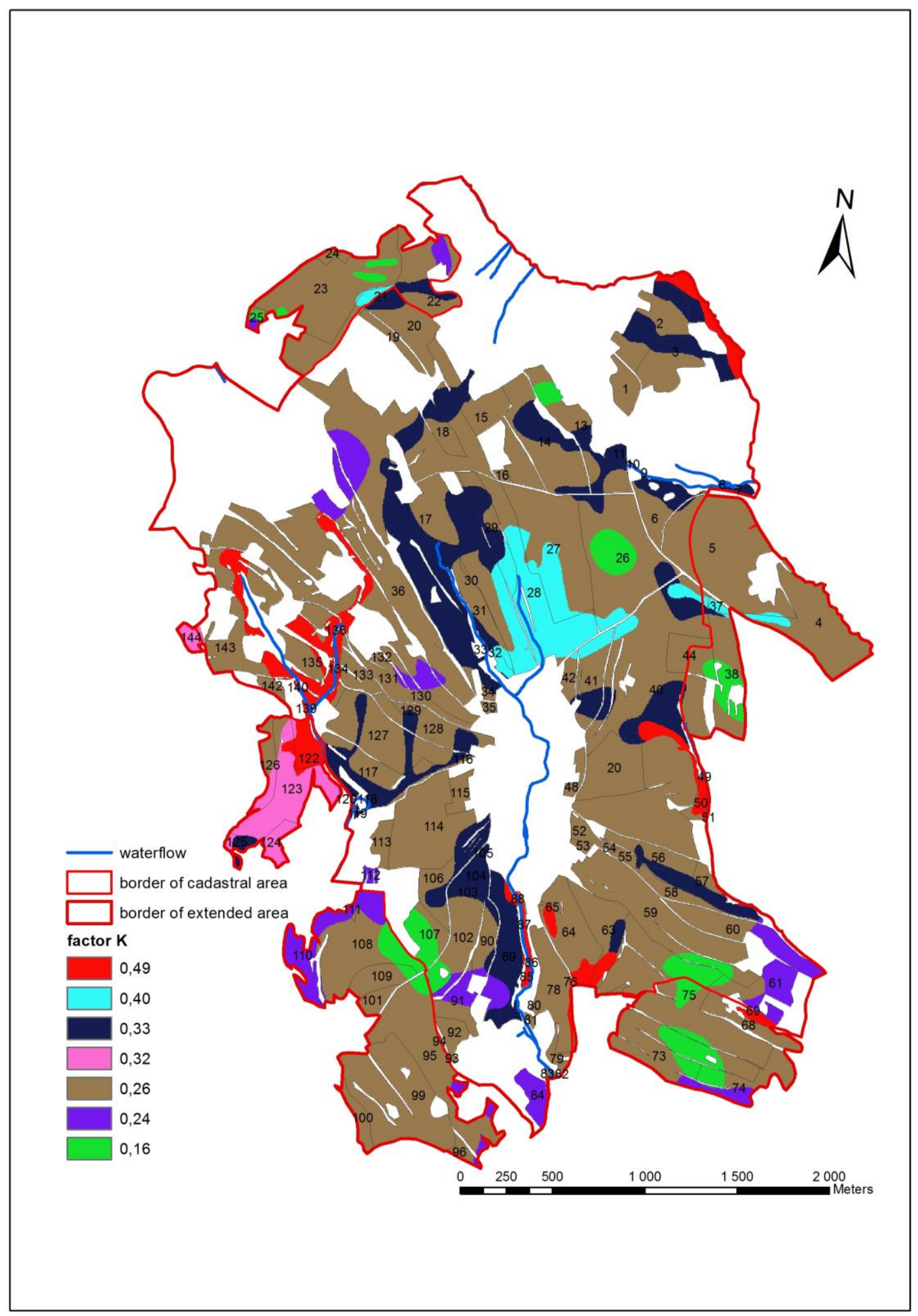

Fig 5. Values of factor K of the cadastral area Rovečné (layer K_factor).

The influence of slope gradient and slope length on the amount of soil loss is expressed by topographic factor LS, which is graphically displayed in the form of raster layer LS_factor in the Fig. 6. Some similarities of the graphical representation of LS factor and of the average annual soil loss (Fig. 8) are evident. The intensity of erosion is in a certain correlation with the increasing value of LS factor. 


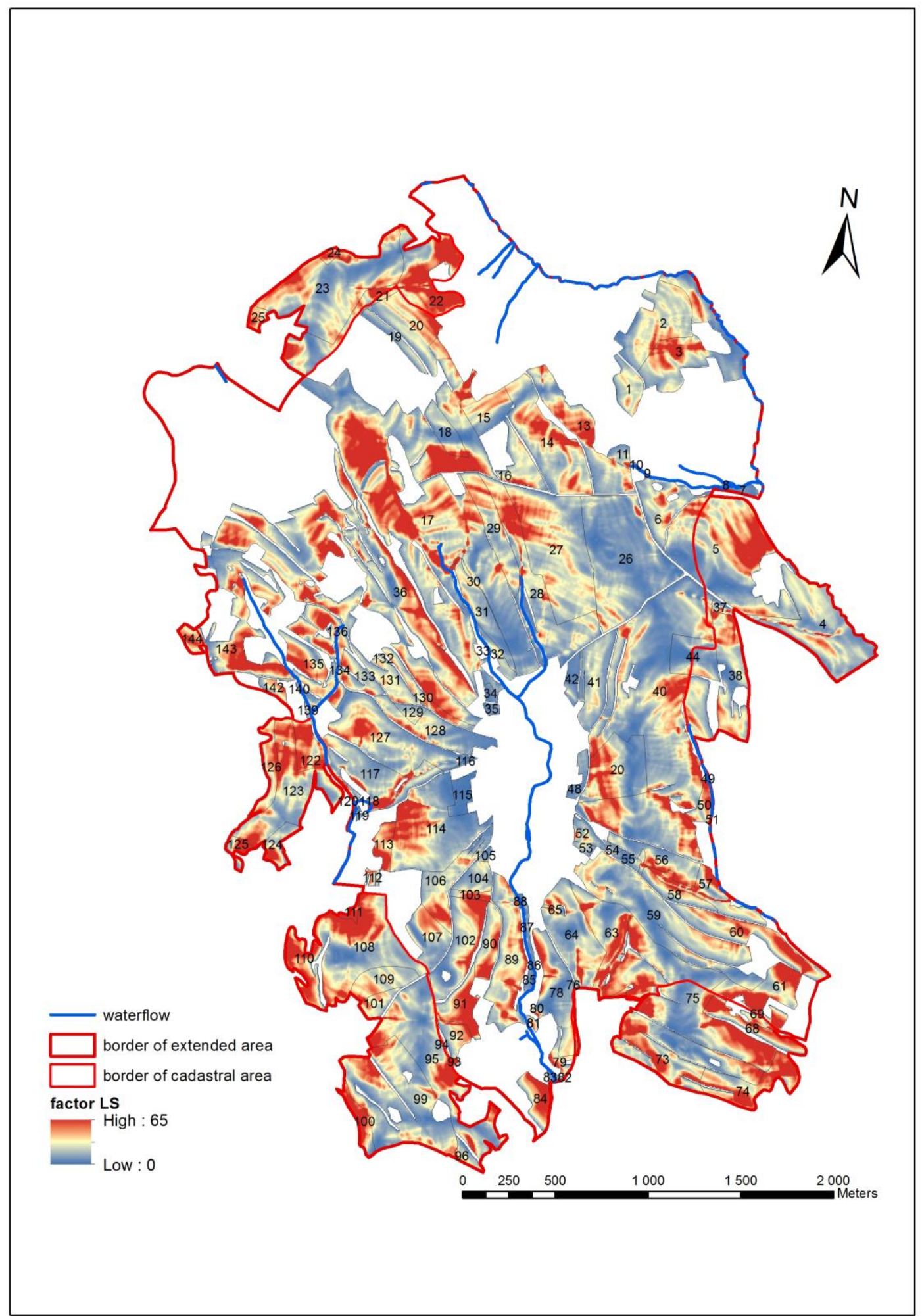

Fig 6. Values of factor LS of the cadastral area Rovečné (layer LS_factor).

Calculated mean values of factor $C$ differ according to the used crop rotation (Tab. 2). The highest erosion control effect of vegetation was found out in the crop rotation no. 1 , on the contrary the crop rotation no. 2 had the worst erosion control effect. The difference is caused by represented crops and their sequence in crop rotation (Fig. 7). The values of factor $\mathrm{C}$ on the individual blocks are shown in Fig. 7. 
Tab 2. Values of original factor $C$ (without erosion control measures) and after $1^{\text {st }}$ and $2^{\text {nd }}$ draft of erosion control measures.

\begin{tabular}{|c|c|c|c|c|c|}
\hline Value of factor C/crop rotation & 1 & 2 & 3 & 4 & 5 \\
\hline without erosion control measures & 0.181 & 0.326 & 0.260 & 0.199 & 0.220 \\
\hline $\begin{array}{c}\text { after } 1^{\text {st }} \text { draft of erosion control } \\
\text { measures }\end{array}$ & 0.069 & 0.154 & 0.158 & 0.106 & 0.155 \\
\hline $\begin{array}{c}\text { after } 2^{\text {nd }} \text { draft of erosion control } \\
\text { measures }\end{array}$ & 0.069 & 0.149 & 0.148 & 0.091 & 0.146 \\
\hline
\end{tabular}

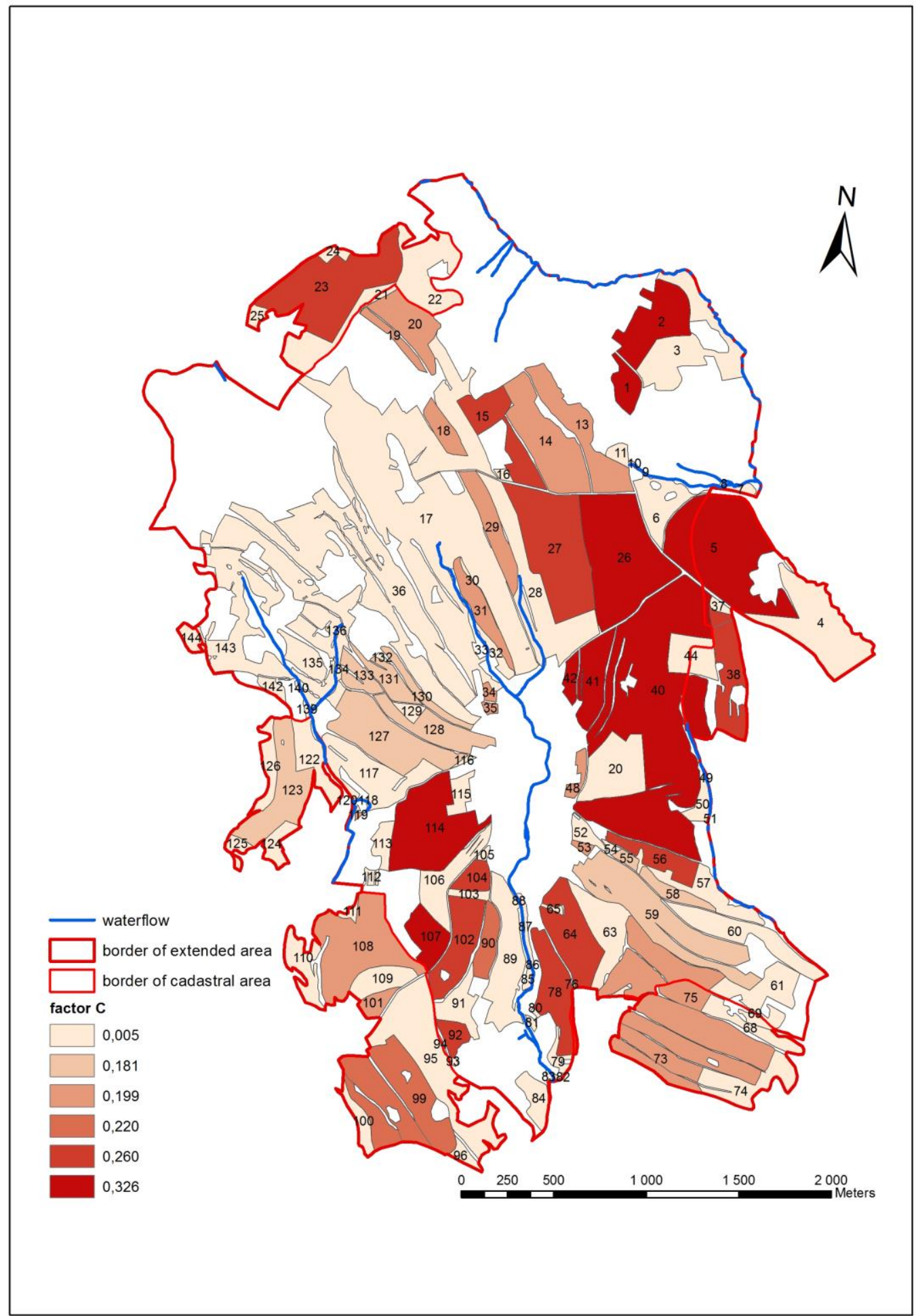

Fig 7. Values of factor $C$ according to the different crop rotations (layer $C \_$factor). 
Information on the support practices or factor $P$ values in the site was collected through field observation. $P$ factor value is 1 , which indicates no physical evidence of erosion control in the area of interest.

Individual layers were overlaid and multiplied according to the USLE into one combined layer ( $A$ _erosion) which shows the erosion rate (Fig. 8) and subsequently erosion vulnerability of the area of interest (Fig. 9).

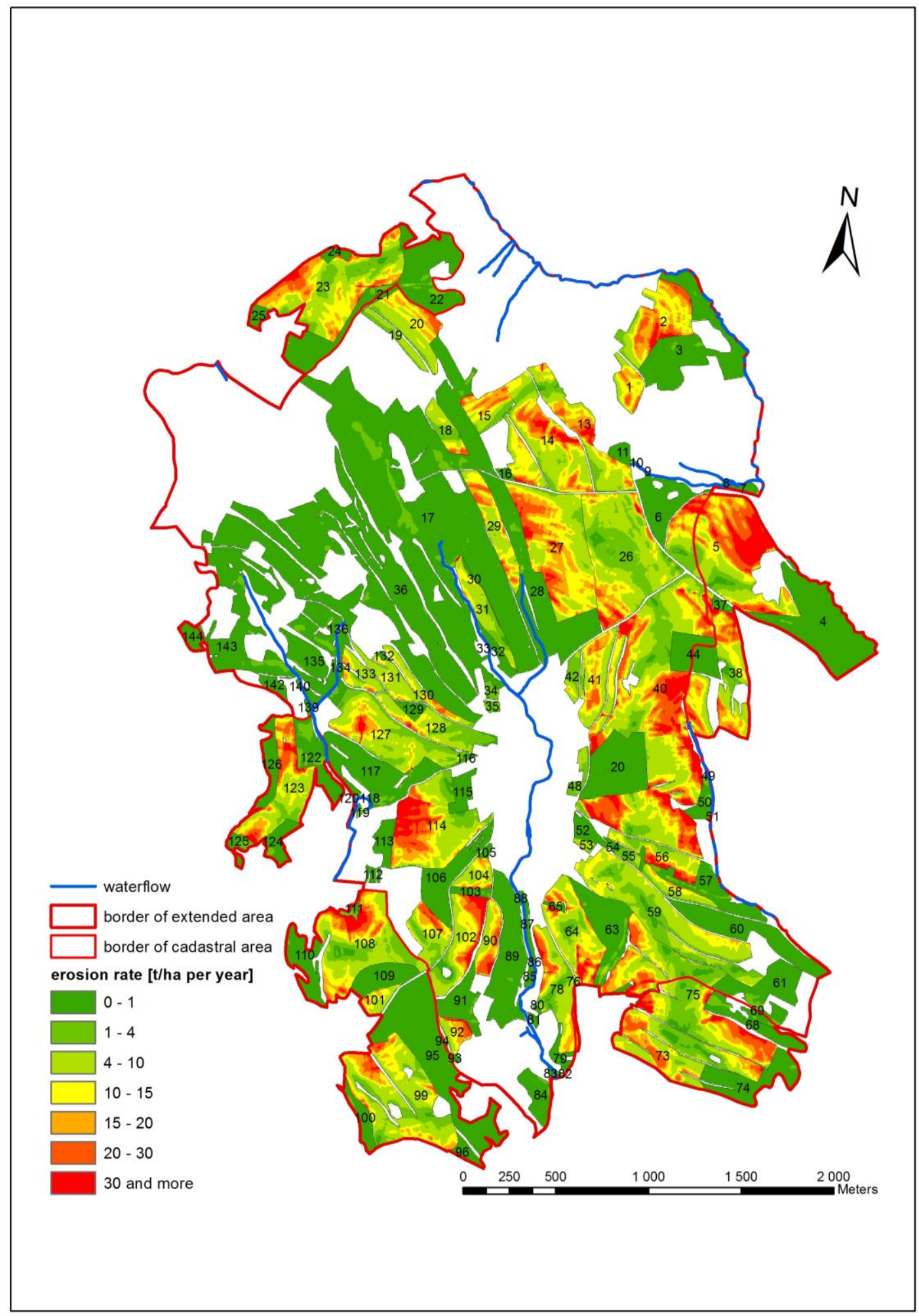

Fig 8. Erosion rate in t.ha-1 per year of the cadastral area Rovečné (layer A_erosion). 


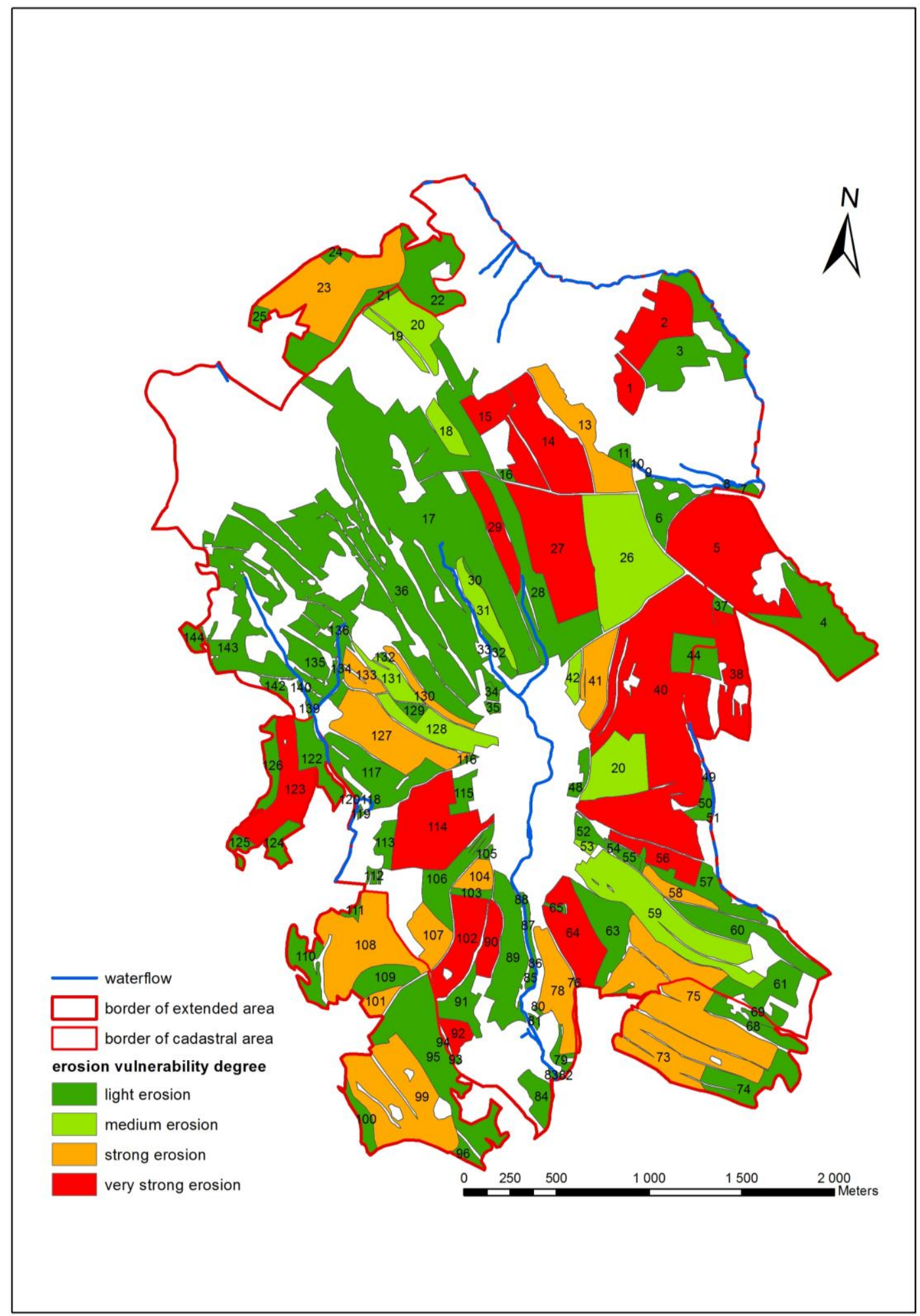

Fig 9. Erosion vulnerability degrees of individual blocks of the cadastral area Rovečné.

Fig. 8 and 9 show that blocks of arable land are vulnerable to various degrees of erosion, compared to that - blocks with grassland are almost without threat.

The map in Fig. 9 shows four erosion vulnerability degrees determined on the basis of calculated annual soil loss $A$ and soil loss tolerance $\mathrm{T}$, which is $4 \mathrm{t}^{\mathrm{th}} \mathrm{a}^{-1}$ per year for moderately deep and deep soils in the area. It means that $44.79 \%$ of the land area is threatened by light erosion, $10.03 \%$ by medium erosion, $19.08 \%$ by strong erosion and $26.10 \%$ by very strong erosion. The results show a strong and very strong vulnerability of large areas of arable land to water erosion, and therefore a need of a draft of appropriate erosion control measures. 


\subsection{First Phase of the Design of Erosion Control Measures}

Design of erosion control measures was based on a valid methodology (Janeček et al., 2012), which states that care should be taken not only to maximize the effect of the proposed soil conservation measures, but also should ensure their feasibility and integration into agricultural practices. That means, as Polách et al. (1987) say, that the managing subject should, in their own interest, respect and strive to adopt the proposed erosion control measures. As well as, a draft of erosion control measures should correspond with the needs and interests of farming cooperatives.

The change of blocks/plots organization as well as the cultures delimitation were not considered in the design of erosion control measures due to the considerable fragmentation of the cadastral area, the resulting severity of changes of plots size and shape and also due to the relatively high amount of surfaces with a protective grassing ( $45.5 \%$ of agricultural land) before the erosion control measures design.

Within erosion control design, measures, that provide erosion protection without reducing the area of arable land, that shorten the time period without vegetation cover of land or protective effects of crop residues, were proposed. The mentioned measures were proposed because of their lower economic and technical demands and their minimal impact on existing representation of crops and farming methods in the area of interest corresponding with the economic effect that brings just the current composition of crops. Within proposed measures, current crop rotation was not substitute by crops more resistant to erosion, but only crops with small erosion control effect were identified and minimization method of tillage, using intercropping and crop residues, was designed. They not only provide protection of the soil surface, but also have improving effect on its structure and content of organic matter (Badalíková and Hrubý, 2009).

Maize and winter rape belongs to the crops, which have within the current method of cultivation bad erosion effect. The following measures have been therefore proposed:

- maize sowing to fully loosened over frozen intercrops and crops and crop residues,

- summer no-tillage sowing of winter rape to stubble,

- shift of stubble cultivation and tillage into the period with a lower occurrence of torrential rains.

During application of proposed measures, number of pitfalls associated with these measures should be taken into account.

In connection with the sowing of the maize to fully loosened over frozen intercrops and crop residues, it should be mentioned a few facts, which resulting from the use of this technology. The main objective, which Procházková et al. (2011) state, is the protection of soil and the environment. The fact, that this is a very effective erosion control measure, is reflecting by the resulting value of the factor $C$ that contains mentioned measure in crop rotation no. 2 and 3 (Tab. 3). Procházková et al. (2011), however, also state a certain problem of this measure, which consist in the fact that the soil on no-tillage plots with over frozen intercrops warms more slowly in the spring due to the presence of crops residues, higher bulk density, moisture content, and thus a higher thermal conductivity of soil. This may lead to a delay of the sowing deadline or to a slowdown of the initial growth of maize in some years. Another problem is the large amount of possible crops residues on the soil surface, which can cause problems with seed quality and protection against weeds. When planting the intercrops, it is effective to include deeper loosening of the soil surface with its levelling and intercrops sowing after stubble cultivation (taking into account the needed warming of the soil in the spring, especially in colder areas on clay soils). The last problem, which Procházková et al. (2011) mention, is the need of spring application of non-selective herbicide, which is necessary to expect in most cases.

Stubble cultivation with following deeper loosening of soil surface and its levelling was proposed before intercrops (mustard) sowing due to climatic and soil conditions of the cadastral area Rovečné. This cultivation resulted in the higher value of factor $C$ in crop rotation with maize. The need of non-selective herbicide application is often indisputable necessity to achieve the required yields of maize during this cultivation, but in connection of this measure as a tool of the soil and environment protection, this fact becomes somewhat problematic. 
Summer no-tillage sowing of winter rape to stubble was the second mentioned erosion control measure. Winter wheat and spring barley were the most frequent forecrops for winter rape on the study site. The main reason for this measure draft was to reduce soil erosion risks in the periods of torrential rains, when, as state Podhrázská and Dufková (2005), plots prepared for sowing and plots sown with summer intercrops and winter rape are heavily threatened by erosion. As a way-out they mention the summer no-tillage sowing of winter rape. Janeček et al. (2012) states that winter rape sown into stubble compensates germination and yield of winter rape sown in traditional tillage. Procházková et al. (2011), however, mention certain restrictions in minimization technologies using which are related mainly to regulation of second growth and leaving the straw on the field. It is very important to crush the straw well, evenly spread it out over the soil, adjust the C:N ratio and immediately integrated the straw into the soil when leaving the straw on the field before sowing winter rape, and all this due to the very short intervegetation period and generally higher requirements of winter rape on the quality of sowing. Even when following these precautions associated with leaving the straw in the field, it is necessary to expect the inhibitory effect of straw and second growth, while more serious problems occur within the cultivation of winter rape after spring barley than after winter wheat.

Shift of stubble cultivation and tillage into the period with a lower occurrence of torrential rains was the last proposed measure against water erosion. It would be the best to completely eliminate plowing from the erosion point of view, but it is not the best solution. For example, Pivnička (2002) points out the importance of plowing. He states that plowing turns the soil, blends it, loosens it and crumbles it, which means increasing of the porosity, permeability to water, the amount of air in the soil and the dynamics of its replacement, while the specific gravity of the softened soil decreases. Weakening and destruction of weeds, incorporation of manure and crop residues are also the important functions of plowing. Pivnička (2002) also states that the importance of farmyard manure, which is incorporated into the soil during the plowing, lies in the fact that the soil is supplied with organic matter and certain amount of humus.

Usefulness of manure for soil appears in many other ways. For example, Mašiček et al. (2013) examined the effect of adding manure to the soil on the water infiltration velocity. The research, which was carried out on arable land with vegetation of spring wheat during the growing season of 2012, showed that average higher rate of infiltration was found out on the fertilized plot compared to unfertilized one during the whole growing season.

Pivnička (2002) also states that water erosion rate is proportional also to the quantity of humus in the soil, whose amount is increasing with delivery of matured manure into the soil. From this fact, it is possible to deduced substantiation for the inclusion of both no-tillage, as well as traditional techniques with tillage into crop rotations on vulnerable plots. A suitable combination of these techniques could thus probably achieve effective long-term agricultural production in the areas threatened by water erosion.

The result of proposed soil protective technologies projected into different crop rotations was a significant decreasing of factor C (Tab. 2, Fig. 10), and thus the average annual soil loss in all areas threatened by erosion (Fig. 11). Erosion vulnerability degrees after erosion control measures design are shown on the map in Fig. 12. Vulnerability of individual plots by erosion decreases by one level, in some cases by two degrees (blocks no. 1, 2, 14, 15, 29, 40, 64, 114, $123,127,130,133)$ through erosion control measures design. The decreasing of average annual soil loss by water erosion also occurred at the block no. 18, where change in the vulnerability degree has not been directly observed. The highest vulnerability degree (4) was completely eliminated through erosion control measures. Acreage of the agricultural land in each category of erosion vulnerability degrees before and after the first draft of erosion control measures is shown in Tab. 3. 


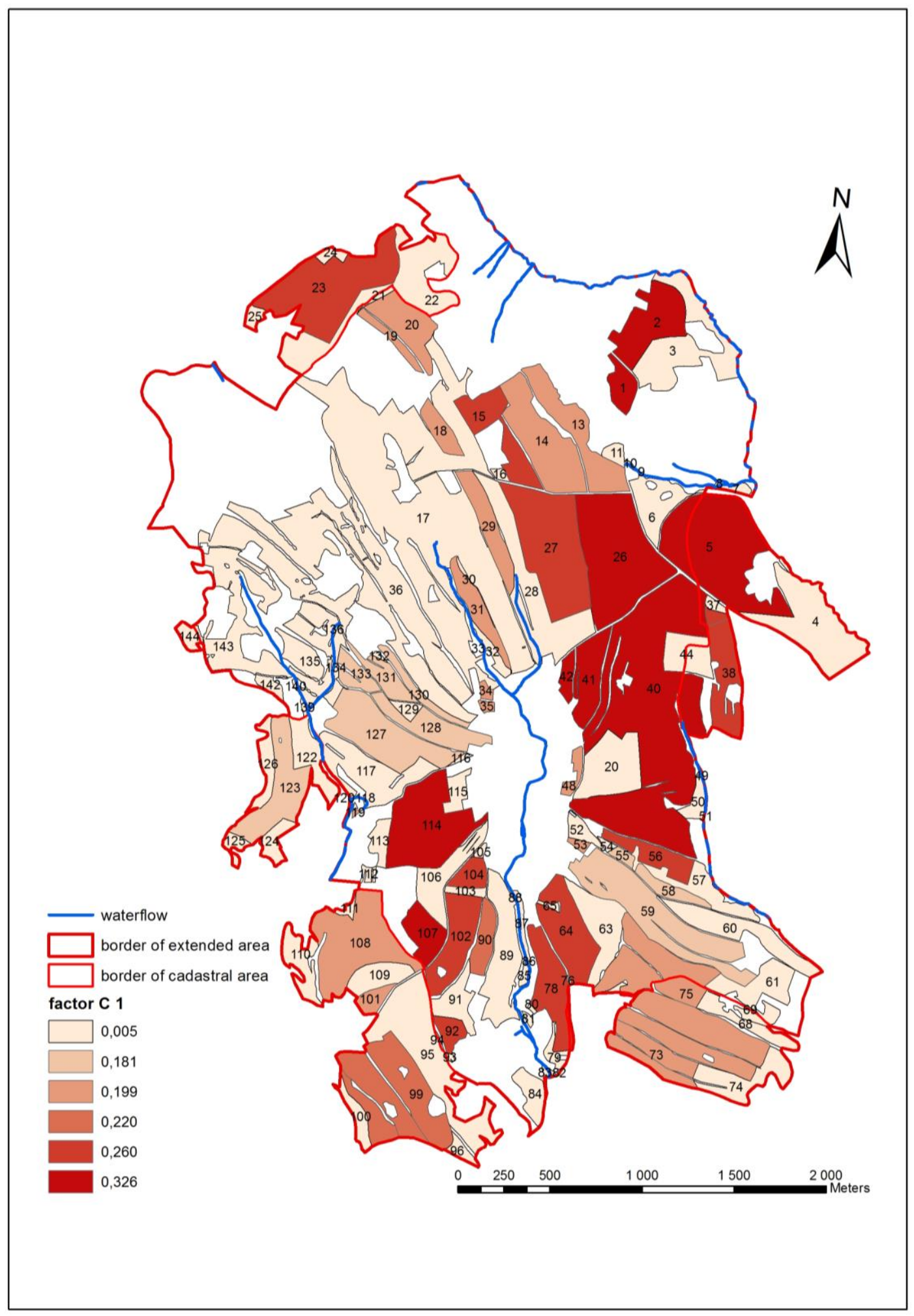

Fig 10. Values of factor $C$ after $1^{\text {st }}$ erosion control measures design. 


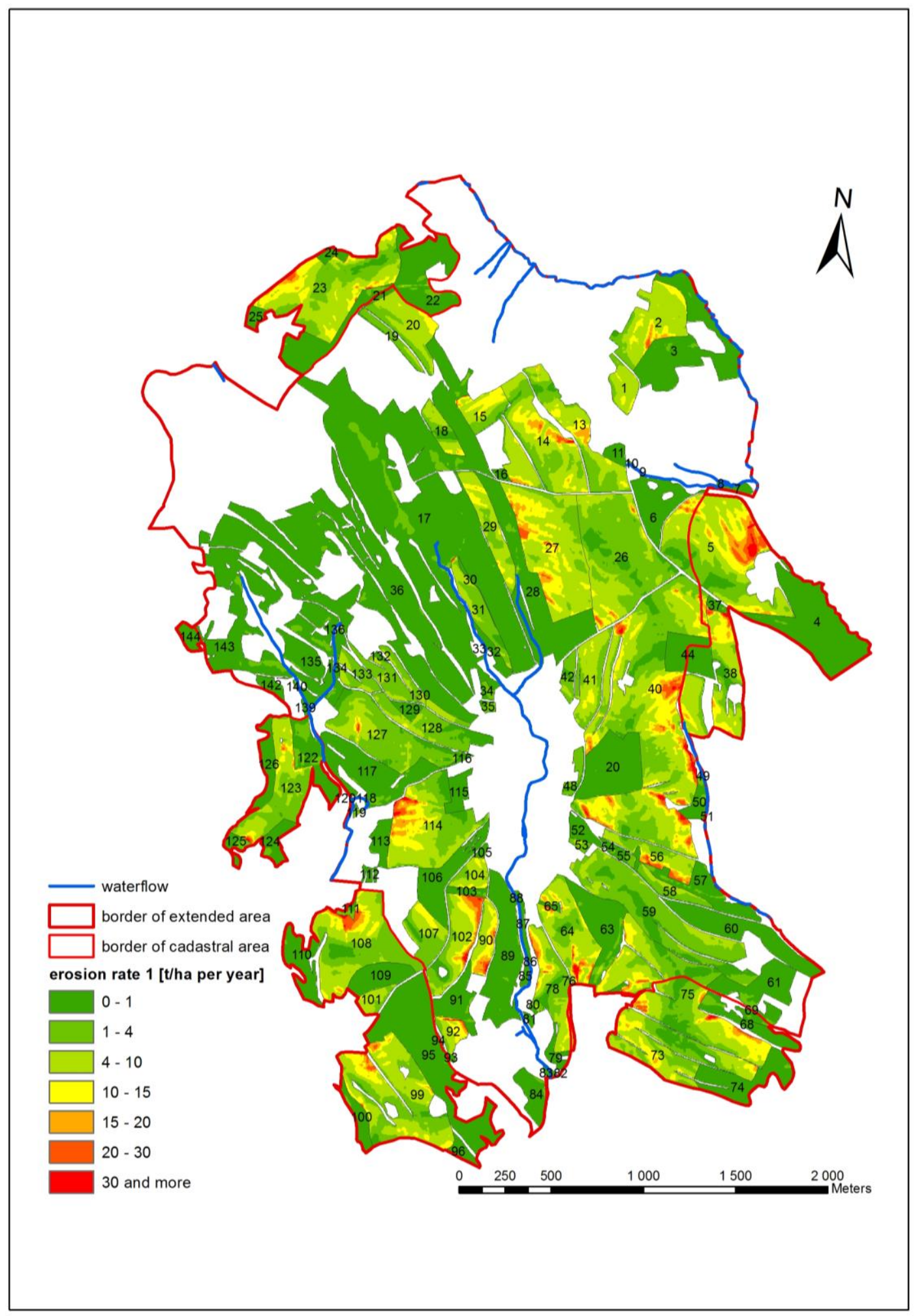

Fig 11. Erosion rate in tha $^{-1}$ per year after $1^{\text {st }}$ erosion control measures design (layer A1_erosion). 


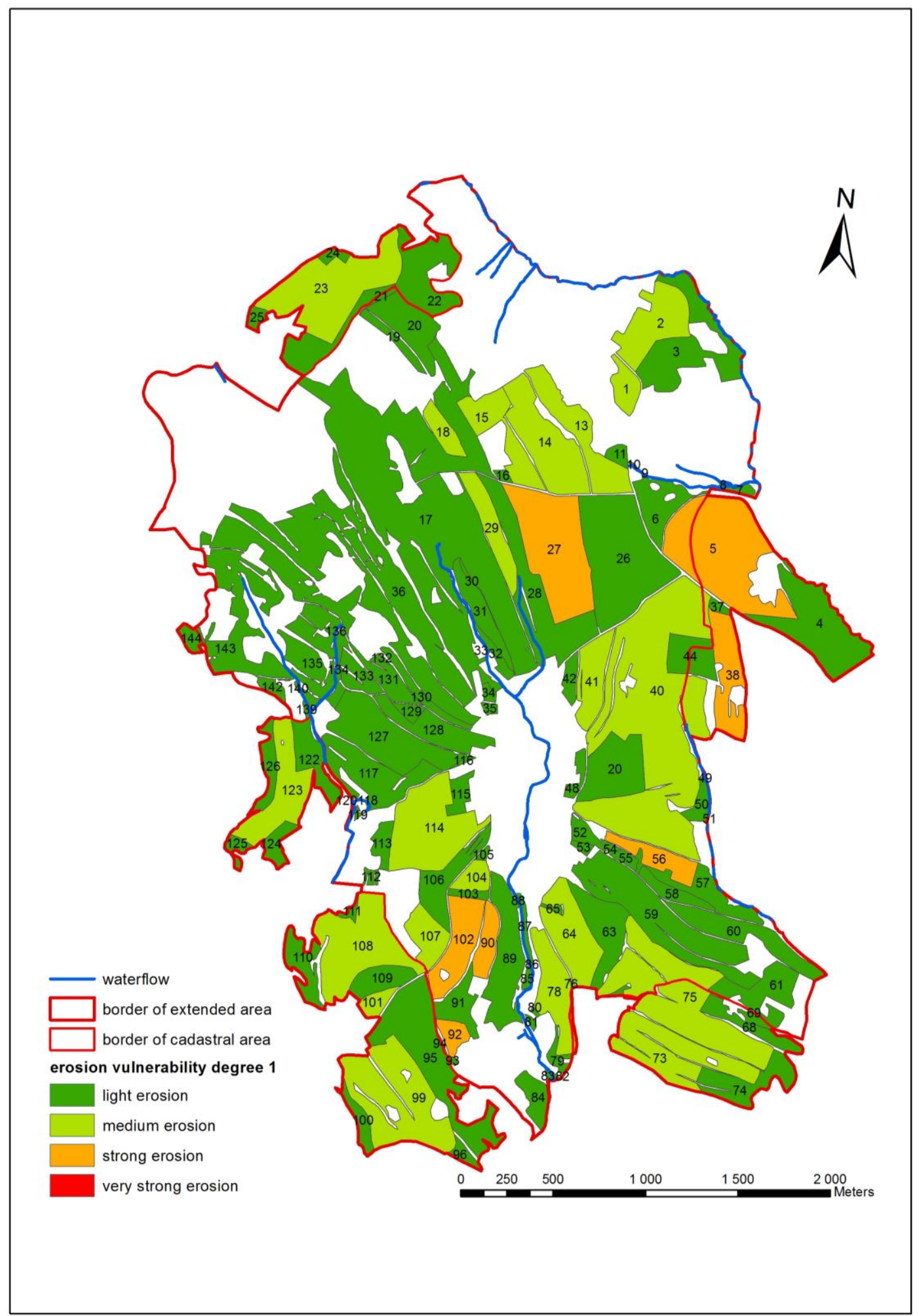

Fig 12. Erosion vulnerability degrees of individual blocks after $1^{\text {st }}$ erosion control measures design. 
Tab 3. Acreage of the agricultural land in each category of erosion vulnerability degrees before and after erosion control measures design.

\begin{tabular}{|c|c|c|c|}
\hline \multirow{2}{*}{$\begin{array}{c}\text { Erosion vulnerability } \\
\text { degree }\end{array}$} & $\begin{array}{c}|c| \\
\text { before erosion } \\
\text { control measures } \\
\text { design }\end{array}$ & $\begin{array}{c}\text { after 1st erosion } \\
\text { control measures } \\
\text { design }\end{array}$ & $\begin{array}{c}\text { after 2nd erosion } \\
\text { control measures } \\
\text { design }\end{array}$ \\
\hline 1. light erosion & $366.90(44.79)$ & $468.02(57.13)$ & $471.01(57.50)$ \\
\hline 2. medium erosion & $82.16(10.03)$ & $276.20(33.72)$ & $286.74(35.00)$ \\
\hline 3. strong erosion & $156.34(19.08)$ & $74.99(9.15)$ & $61.44(7.50)$ \\
\hline $\begin{array}{c}\text { 4. very strong } \\
\text { erosion }\end{array}$ & $213.80(26.10)$ & $0.00(0.00)$ & $0.00(0.00)$ \\
\hline
\end{tabular}

\subsection{Second Phase of the Design of Erosion Control Measures}

Proposed erosion control measures for maize and winter rape were amended, in the second erosion control measures design, with measures including soil protection for cereal crops planting. No-tillage cultivation was proposed within spring barley planting after maize and within oat and winter wheat planting. As medium degree of erosion vulnerability occurred at most of plots even after the application of the first erosion control measures design (in some cases strong erosion occurred), measures were not intended to the specific plots, but to the crop rotations as a whole. The effort was therefore to reduce the value of factor $C$ on the largest area of arable land in the study area. Erosion control measures were, however, proposed with regard to the fact that tillage must be retained in each five-year crop rotation at least two to three times, because of the above mentioned reasons. 


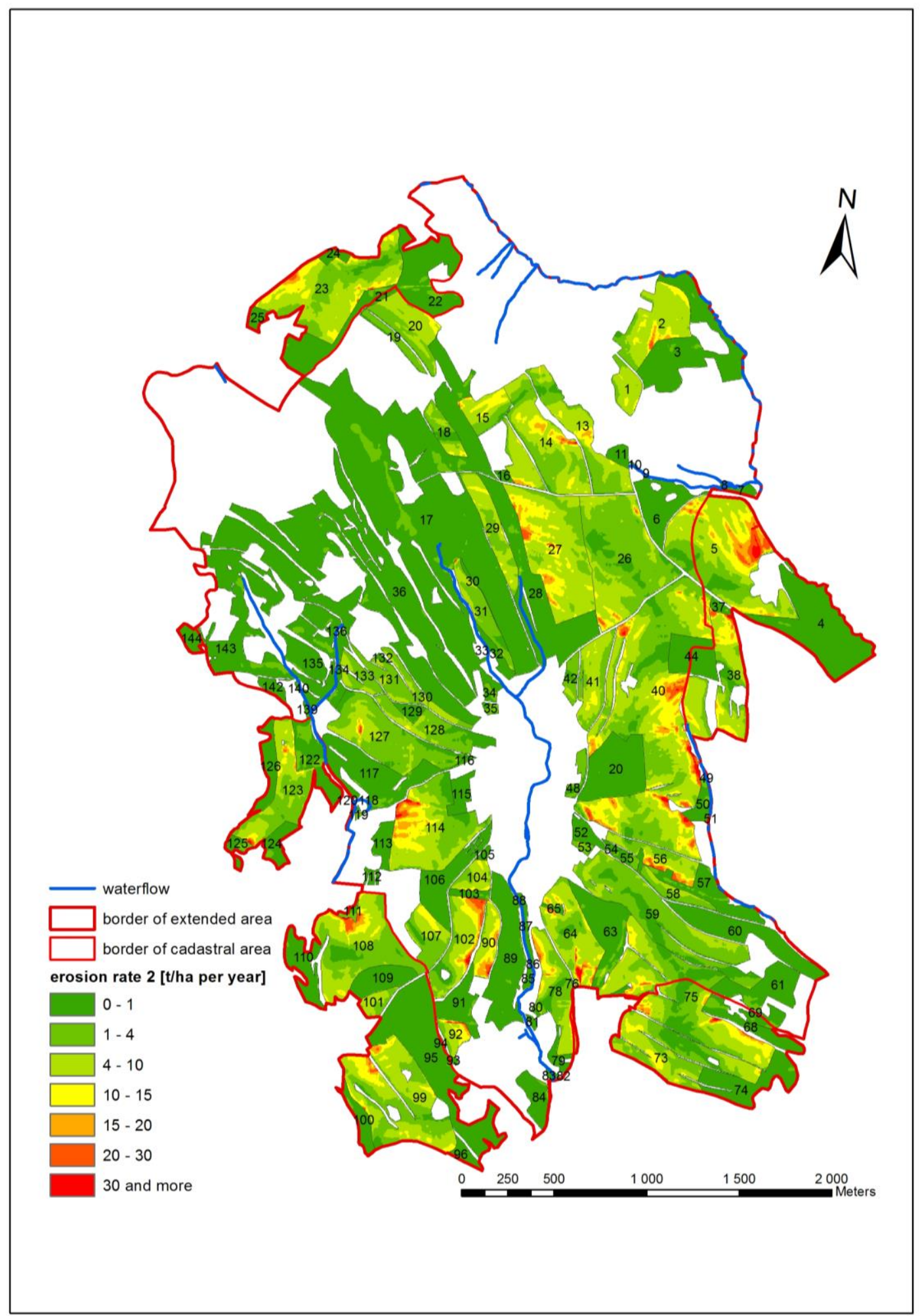

Fig 13. Erosion rate in t.ha-1 per year after $2^{\text {nd }}$ erosion control measures design (layer A2_erosion).

It was found out after the calculation of the factor $C$ (Tab. 2) and the average annual soil loss, that the proposed measures did not produce, against expectations, a significant effect consisting in a significant reduction in the loss of soil (Fig. 13). The erosion vulnerability degree was reduced only in three cases - on the soil blocks no. 18, 38 and 56 (Fig. 14). The comparison of the acreage of the agricultural land in the individual categories of erosion vulnerability degree before and after first and second proposal of erosion control measures is shown in Tab. 3. 


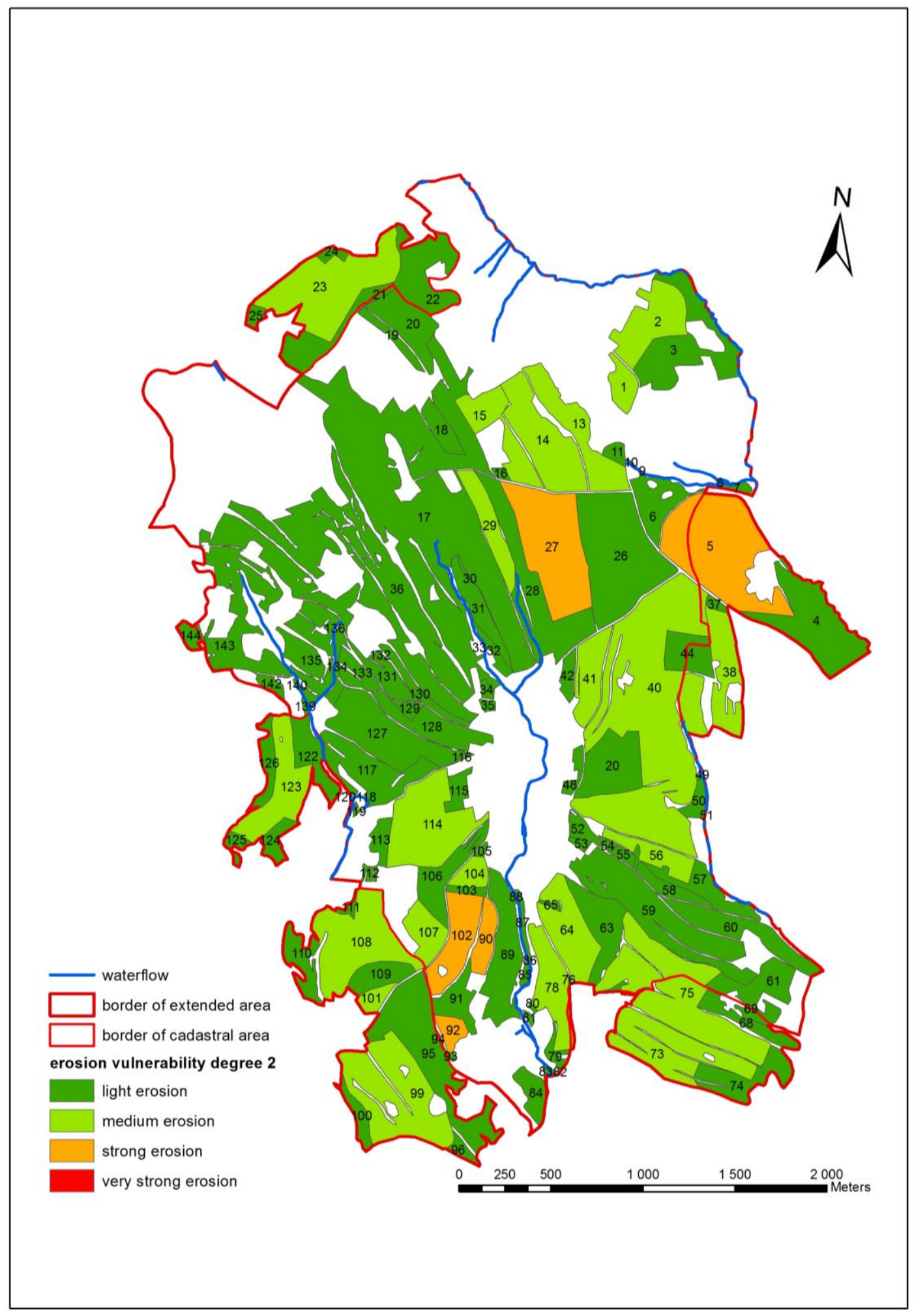

Fig 14. Erosion vulnerability degrees of individual blocks after 2nd erosion control measures design.

Some problematic circumstances, that e.g. Procházková et al. (2011) indicate, relate with the proposed erosion control measures. These include no-tillage and planting of spring barley after maize. This technology can be implemented without major restrictions for maize silage, when smaller amount of crop residues remains on the soil. The larger amount of crop residues after grain maize, while using no-tillage practices, can negatively affect the quality of planting, the initial growth of spring barley and the growth of fungal diseases. 


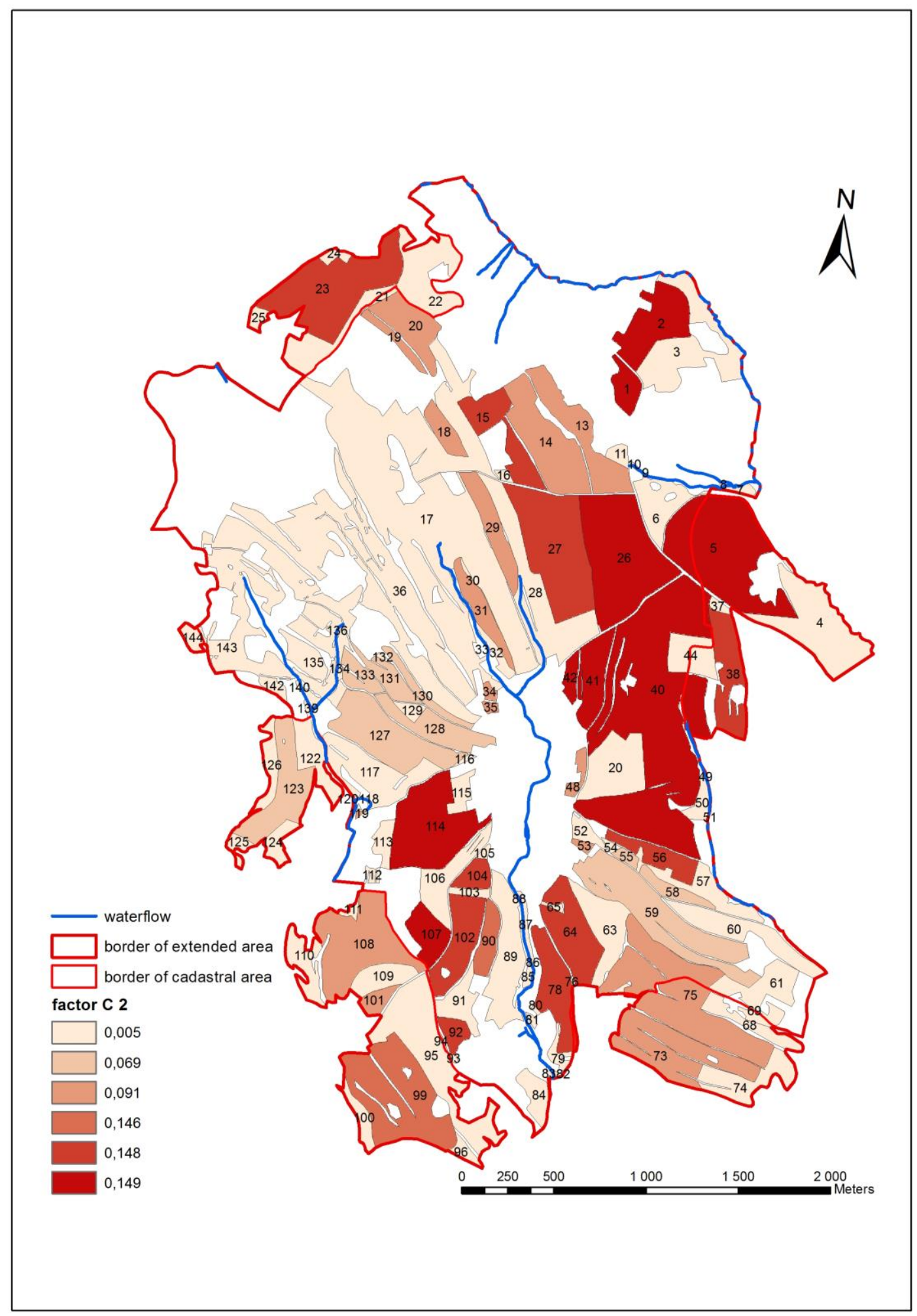

Fig 15. Values of factor $C$ after $2^{\text {nd }}$ erosion control measures design.

The question is, whether no-tillage technologies in selected cereal actually realize, or use only the first propose of erosion control measures. Taking into account the possible drawbacks associated with the introduction of these technologies, especially complications with cultivation primarily barley, but also advantages in the form of a very weak, but indisputable erosion efficiency, becomes this variation matter for discussion.

Another possible proposal of erosion protection of study area, this one has a theoretical character not included in the calculations, could be an application of protective grassing within blocks of arable land in areas where there is noticeable erosion (Fig. 15). Protective grassing should be 
designed with respect to the territorial conditions, in combination with no-tillage technologies applied in crop rotations in selected crops, to achieve adequate protection against erosion.

Due to the character of the area, especially in the context of the current state when arable land and grassing are represented here, it does not seem to be efficient and cost-effective to approach to more extensive biotechnological measures in the form of erosion control balks, infiltration strips and others, which are already partially represented in stragglingly occurring linear vegetation. Biotechnical erosion control measure would be appropriate to realize just on the block no. 5 in the form of a redevelopment of the concentrated runoff path. Surface runoff from the part of the plot is concentrated into the thalweg and outflowing water is causing erosion furrows. Currently these furrows are restored. Cultivation of adequate crops along with application of proposed minimization technologies (elimination of crop rotation with maize, sowing of maize to fully loosened over frozen intercrops and crop residues, no-tillage sowing of winter rape etc.) could prevented this phenomenon at least temporarily. Grassing of this waterway would bring more certainty and undoubtedly permanent erosion control of the area.

\section{Conclusion}

Evaluation of the vulnerability of agricultural land by water erosion, including the erosion control measures design, was done using GIS on example of the cadastral area Rovečné. The proposed measures should improve the current situation and also contribute to preservation of agricultural activity in this area in a form close to the current situation.

The importance of GIS consists in the fact that they allow rapid and accurate quantification of physical-geographical characteristics of large areas in combination with efficient and accurate way of the USLE calculation. Graphical representation of the factors of K, LS, C and of the result of USLE itself in the individual map layers provides a quick orientation in erosion conditions of the study area. Individual erosion control measures can be specifically applied through these outputs and alternative solutions of soil erosion protection with immediate presentation of the effect of the proposed measures on specific plots can be proposed.

Significant losses exceeded tolerable soil loss of study area according to the calculation of USLE factors and determination of annual average soil loss. It has been shown, before proposing of erosion control measures, that $26.10 \%$ of the agriculture soil is threatened by very strong erosion, $19.08 \%$ by strong erosion, $10.03 \%$ by medium erosion, and $44.79 \%$ of the land area is threatened by light erosion. On the basis of these results, proposal of erosion control measures was made, consisting in the introduction of no-tillage technologies for the cultivation and planting mainly of maize and winter rape, and also in the second phase of spring barley and in one case, oat and winter wheat. Recalculation of the annual average soil loss after erosion control measures proposal showed a significant effect of these measures on water erosion decrease in the study area. The highest vulnerability degree (4) was completely eliminated through erosion control measures. The area of land threatened by strong erosion was reduced to $7.5 \%$ of agricultural land, area of land threatened by medium erosion increased to $35.0 \%$ and light erosion to $57.5 \%$. Further improvements in soil loss decrease, especially on exposed parts of blocks of arable land, would provide grassing and redevelopment of the concentrated runoff path specifically on the plot no. 5.

Erosion control measures proposal, which has to serve effectively to man, soil and landscape, cannot be done for its own sake and only by the austere rules, but always needs to be the most appropriate to incorporate all the determinants of a particular area with its capabilities, but also limitations, both natural and anthropogenic. Only with such an approach to the landscape, which is based on its understanding and long-term development, it is possible to propose measures that will serve well for current and future generations.

\section{Acknowledgment}

The paper was elaborated with the support of the Institutional Plan of Mendel University in Brno no. 13.9 "Innovation of the subject Computer Design - the practical use of GIS within hydrological analyses solving". 
[1] Auzet, V., Poesen, J. \& Valentin, C. (2004). Editorial. Soil surface characteristics: dynamics and impact on soil erosion. Earth Surface Processes and Landforms 29(9), 1063-1169. DOI: 10.1002/esp.1101.

[2] Badalíková, B. \& Hrubý, J. (2009). Využití netradičních meziplodin v protierozní ochraně půdy. Zemědělský výzkum Troubsko.

[3] Barthès, B. \& Roose, E. (2002). Aggregate stability as an indicator of soil susceptibility to runoff and erosion: validation at several levels. Catena 47(2), 133-149. DOI: 10.1016/S03418162(01)00180-1.

[4] Bartsch, K. P., van Miegroet, H., Boettinger, J. \& Dobrowolski, J. P. (2002). Using empirical erosion models and GIS to determine erosion risk at Camp Williams, Utah. Journal of Soil and Water Conservation 57(1), 29-36.

[5] Dumbrovský, M. et al. (2008). Základní topografické a hydrologické nástroje a výpočet erozního smyvu v prostředí ArcGIS. VUT Brno.

[6] Efe, R., Ekinci, D. \& Curebel, I. (2000). Erosion analysis of Sahin watershed (NW of Turkey) using GIS based on RUSLE (3D) method. Journal of Applied Sciences 8(1), 49-58. DOI: 10.3923/jas.2008.49.58.

[7] Feng, X., Wang, Y., Chen, L., Fu, B. \& Bai, G. (2010). Modeling soil erosion and its response to land-use change in hilly catchments of the Chinese Loess Plateau. Geomorphology 118(3-4), 239-248. DOI: 10.1016/j.geomorph.2010.01.004.

[8] Ferro, V. \& Minacapilli, M. (1995.) Sediment delivery processes at basin scale. Hydrological Sciences Journal 40(6), 703-717. DOI: 10.1080/02626669509491460.

[9] Fistikoglu, O. \& Harmancioglu, N. B. (2002). Integration of GIS with USLE in assessment of soil erosion. Water Resources Management 16(6), 447-467. DOI: 10.1023/A:1022282125760.

[10] Geletič, J. et al. (2013). Úvod do ArcGIS 10. Olomouc: Palacký University.

[11] Hernando, D. \& Romana, M. G. (2015). Estimating the rainfall erosivity factor from monthly precipitation data in the Madrid Region (Spain). Journal of Hydrology and Hydromechanics 63(1), 55-62. DOI: 10.1515/johh-2015-0003.

[12] Janeček, M. et al. (2012). Ochrana zemědělské půdy před erozí - metodika. Czech Agricultural University in Prague.

[13] Kuok, K. K. K., Mah, D. Y. S. \& Chiu, P. C. (2013). Evaluation of C and P factors in Universal Soil Loss Equation on trapping sediment: case study of Santubong River. Journal of Water Resource and Protection 5(12), 1149-1154. DOI: 10.4236/jwarp.2013.512121.

[14] Lal, R. (2006). Encyclopedia of soil science. Tailor \& Francis Group.

[15] Longley, P. A., Goodchild, M. F., Maguire, D. J. \& Rhind, D. W. (2011). Geographic Information Systems and Science. Hoboken: John Wiley and Sons.

[16] Mašíček, T. (2010). Retenční potenciál povodí řeky Fryšávky [Ph.D. thesis]. Mendel University in Brno.

[17] Mašíček, T., Toman, F \& Jandák, J. (2013). Porovnání infiltrační schopnosti hnojené a nehnojené orné půdy. Úroda 61(12), 308-311.

[18] Mašíček, T. \& Ždímal, V. (2014). Inovace předmětu „Počitačové projektováni“ - praktické využití GIS při řešení hydrologických analýz [Methodical worksheets]. Mendel University in Brno.

[19] Morgan, R. P. C. (2009). Soil erosion and conservation. John Wiley \& Sons. 
[20] Mukherjee, S., Joshi, P. K., Mukherjee, S., Ghosh, A., Garg, R. D. \& Mukhopadhyay, A. (2014). Evaluation of vertical accuracy of open source Digital Elevation Model (DEM). International Journal of Applied Earth Observation and Geoinformation 21, 205-217. DOI: 10.1016/j.jag.2012.09.004.

[21] Novák, P. et al. (1993). Synthetic soil map of the Czech Republic [1:200 000].

[22] Official announcement of Ministry of Agriculture no. 327/1998 Col., which define the characteristics of the soil ecological units and the procedure for management and updating, in version no. 546/2002 Col.

[23] Panagos, P., Borrelli, P. \& Meusburger, K. (2015). A new European slope length and steepness factor (LS-Factor) for modeling soil erosion by water. Geosciences 5, 117-126. DOI: $10.3390 /$ geosciences5020117.

[24] Pivnička, K. (2002). Aplikovaná ekologie: dlouhodobá udržitelnost rybářské, zemědělské a lesnické produkce. Praha: Karolinum.

[25] Podhrázská, J. \& Dufková, J. (2005). Protierozní ochrana půdy. Mendelova zemědělská a lesnická univerzita v Brně.

[26] Polách, J. et al. (1987). Protierozní ochrana zemědělských pozemků - typizační směrnice. Praha: Státní zemědělské nakladatelství.

[27] Procházková, B. et al. (2011). Minimalizační technologie zpracování pưdy a možnosti jejich využití při ochraně půdy a krajiny [Applied certified methodology]. Mendelova univerzita v Brně.

[28] Renard, K. G., Foster, G. R., Weesies, G. A. \& Porter, J. P. (1991). RUSLE: Revised Universal Soil Loss Equation. Journal of Soil and Water Conservation 46(1), 30-33.

[29] Rodda, H. J. E., Demuth, S. \& Shankar, U. (1999). The application of a GIS based decision support system to predict nitrate leaching to ground water in south Germany. Journal of Hydrological Sciences 44(2), 221-236.

[30] Schmidts, M. (2013). Esri ArcGIS Desktop Associate: Certification Study Guide. Redlands, Ca.: Esri Press.

[31] Shabani, F., Kumar, L. \& Esmaeili, A. (2014). Improvement to the prediction of the USLE K factor. Geomorphology 204(1), 229-234.

DOI: 10.1016/j.geomorph.2013.08.008.

[32] Tolasz, R. et al. (2007). Climate atlas of Czechia. Praha: Czech Hydrometeorological Institute.

[33] van Oost, K. \& Govers, G. (2000). USLE2D: Online manual. Katholieke Universiteit Leuven: URL: http://www.kuleuven.be/geography/frg/modelling/erosion/usle2dhome/.

[34] Williams, J. R. (1975). Sediment-yield prediction with Universal Equation using runoff energy factor. In: Present and Prospective Technology for Predicting Sediment Yields and Sources, ARS-S-40 (pp. 244-252). Washington, DC.: US Department of Agriculture.

[35] Wischmeier, W. H. \& Smith, D. D. (1978). Predicting rainfall erosion losses. A guide to conservation planning. Washington, DC.: US Department of Agriculture.

[36] Zheng, F. (2006). Effect of vegetation changes on soil erosion on the Loess Plateau. Pedosphere 16(4), 420-427. DOI:10.1016/S1002-0160(06)60071-4.

[37] Zheng, M., Liao, Y. \& Jijun, H. (2014). Sediment delivery ratio of single flood events and the influencing factors in a headwater basin of the Chinese Loess Plateau. PLoS One 9(11). DOI: 10.1371/journal.pone.0112594. 